\title{
SYNTHESIS OF OLIGOPEPTIDES OF DEFINED FRAGMENT COMPOSITION
}

\author{
T. Paypanova ${ }^{1}, \mathrm{~T}$. Hristova ${ }^{2}$, R. Cherkezova ${ }^{2}$ \\ 1) Institute of Molecular Biology, Bulgarian Academy of Sciences - Sofia, \\ Bulgaria; \\ 2) Department of Medical and Biological Sciences, Faculty of Dental Medicine, \\ Medical University - Varna, Bulgaria
}

\section{SUMMARY:}

The advantages of the solid-phase peptide synthesis were used. The peptide chain was built on specially processed insoluble polymer resin: Wang- and Rink Amide MBHA-resin. Three new fragment oligopeptides were prepared by activation and condensation of Fmoc-protected amino acids [which were subject of our previous work]. One of the important advantages of Fmoc-strategy is achieved: no continuous unblocking of the protection group is effected and the formed peptide bonds do not break.

Key words: solid-phase peptide synthesis, oligopeptide fragments.

\section{INTRODUCTION:}

Principal methods of peptide synthesis, which are used nowadays, may be divided into two big groups: peptide synthesis in solution and solid-phase peptide synthesis. The difference between these two methods is in the manner of peptide preparation (1).

The peptide synthesis in solution, historically, is the oldest method of peptide synthesis. Through this method, dipeptide preparation is accomplished by controlled bonding of two amino acids, whereas one of them is protected from its $\mathrm{N}$-terminus, and the other one from the $\mathrm{C}$-terminus. After amide bond formation the protected dipeptide is isolated, purified and characterized.

After the introduction of a solid support for peptide synthesis by Merrifield in 1963, the solid-phase peptide synthesis proved its great advantage over the peptide synthesis in solution as regards the speed and efficiency of work with it $(2,3)$. In view of such advantages, the method employed in this work is the method of solid-phase peptide synthesis.

Underlying for the solid-phase peptide synthesis is the idea that the peptide chain formation is carried out on a solid support - specially processed insoluble polymer resin, which, under certain conditions, is linked to the C-terminus of the first amino acid and also under certain conditions, the finished peptide chain is split from the resin at the end of the synthesis (4).
The most widely used are several types of resins by which peptides different in their C-terminus are prepared: Rink Amide MBHA and Wang resins.

Rink Amide MBHA resins are intended for preparation of C-terminal amides using the Fmoc (9Fluorenylmethyloxycarbonyl) strategy. In such resins norleucine is linked to aminomethyl polystyrene. Fmoc-Rinkamid (4-(2',4'-Dimethoxyphenyl-Fmoc-amino methyl)phenoxy)-functional group attached to the polystyrene with $1 \%$ DVB is extremely sensitive to the effect of acids. For that reason, the final peptide is very easily separated from these resins in the presence of highly diluted acid, e.g. 1\% TFA (Trifluoroacetic Acid)/DCM (dichloromethane) or $10 \% \mathrm{AcOH}$ (acetic acid)/DCM.

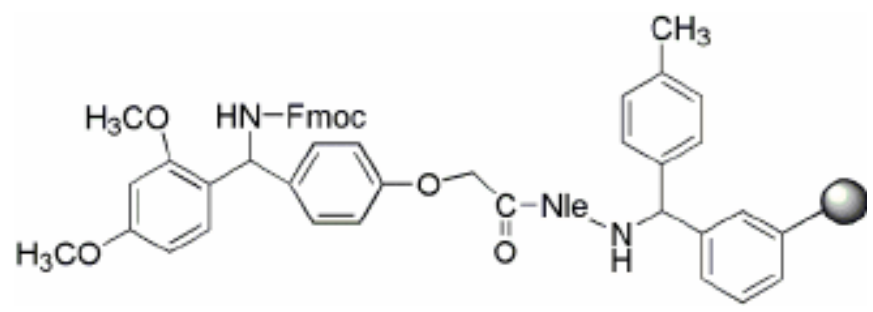

Rink Amide MBHA resin.

The linker in Wang resins is residue of 4(hydroxymethyl)phenoxyacetic acid attached by polyethylene glycol (PEG) on polystyrene, silica gel or other supports that allow syntheses of long peptides.

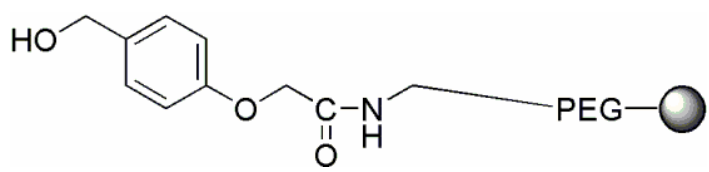

Wang resin.

The purpose of this work is the preparation of oligopeptide fragments with a specific amino acid sequence. 


\section{METHODS AND EQUIPMENT:}

All the syntheses were carried out by a mechanical, manually controlled apparatus-shaker type "Syntax" designed in the German Wool Research Institute - Aachen (Germany).

The resin is put in a Teflon vessel (cell), which outlets are closed by special filters. Filling and emptying of the shaking vessel with DMF (N,N'-dimethylformamide) or unblocking solution (piperidine/DCM) is accomplished through the system of valves and Teflon hoses of the Abimed Company under pressure of 0.5 bar of the nitrogen gas. In order to mix the resin with the organic solvent, the reaction vessel performs shaking movements at a shaking angle of $150 \mathrm{~b}$ and frequency of 50 shakings $/ \mathrm{min}$. The activated amino component is added by hand, after opening the vessel.

\section{PREPARATION OF RESIN}

1. Wang resin: Wang resin is placed in a reaction vessel and is left to swell in DCE (dichlorethane) for one night. After swelling, it is washed by DMF and DCE and then it is possible to set to condensation of the first amino acid.

2. Rink Amide MBHA resin: The Rink amide resin is placed in a reaction vessel and is left to swell in DCM for 1 hour. Unblocking of the Rink amide resin is made after filtration of the solvent and adding of $20 \%$ piperidine/DMF into the residue, when shaking the reaction vessel for 20 minutes. The resin is washed repeatedly by DCM/DMF and finally, with DCM only.

\section{METHODS OF ACTIVATION AND CONDENSATION}

1. Carbodiimide method (DIC/HOBt method): DIC (N,N'-Diisopropylcarbodiimide) are diluted in DCM and added to solution of Fmoc amino acid (Fmoc-AA) and HOBt (1-hydroxybenzotriazole) in DMF and DCM. The reaction mixture is stirred for 5 to 10 minutes at room temperature. The residue is diluted in DMF and is added directly to the resin. The activation time of Fmoc-AA is 30 minutes, as only DMF is used as a solvent.

2. TBTU (HBTU) method: Fmoc-AA and DIPEA (N,N'diisopropylethylenamine) is added to solution of TBTU (O(benzotriazole-1-yl)-1,1,3,3-tetramethylcarbamide tetrafluoroborate) or HBTU (O-(benzotriazole-1-yl)-1,1,3,3tetramethylcarbamide hexafluorophosphate) in DMF, and the reaction mixture is added to the resin. The time required for attachment of the first amino acid to the resin is 40 minutes $(5,6)$.

MONITORING OF THE COMPLETENESS OF THE CONDENSATION PROCESS IN SOLID-PHASE PEPTIDE SYNTHESIS Kaiser Test (7).

The test is based on the formation of colour complex between the ninhydrin reagent and the free amino groups. The reagent for the Kaiser Test consists of the following solutions: ninhydrin in ethanol, phenol in ethanol, water solution of $\mathrm{KCN}$ in pyridine.
A small sample of the resin after unblocking the Fmocgroup immediately before any activation is used as a reference standard and is compared together with the sample taken during condensation. A sample is taken in a small test tube every 20 minutes and one drop of each of the above solutions is added to it gradually. It is heated at boiling water-bath for about 30-60 seconds. If there is a free $\mathrm{NH}_{2}$-group, colouring takes place. The test is considered negative if the initial slight yellow colouring of the sample persists and the reference standard colours dark blue. The test estimation is definitive, if the sample is washed beforehand with DMF and ether.

Aminocarboxylic acids used for the needs of peptide synthesis are manufactured by Bachem.

\section{UNBLOCKING OF PROTECTION GROUPS}

In order to bond the next second amino acid, it is necessary to take off the protection of the first bonded amino acid. This happens by processing the resin with the following solutions: 20\% piperidine/DMF, DMF, DMF/DCE (1:1) and DCE.

These steps of condensation, Kaiser Test and unblocking are repeated for each following Fmoc-AA.

\section{RESULTS:}

Three new fragment oligopeptides were prepared through application of solid-phase peptide synthesis method under the Fmoc strategy.

\section{$\mathrm{NH}_{2}$-Pro-Leu-Gly-OH \\ $\mathrm{NH}_{2}$-Leu-Pro-Gly-OH \\ $\mathrm{NH}_{2}-\mathrm{Pro}-\mathrm{Cav}\left(\mathrm{NO}_{2}\right)-\mathrm{Gly}-\mathrm{NH}_{2}$}

\section{DISCUSSION:}

The subject of our work is to determine a definite number of oligopeptides, which composition is with preliminary assigned (defined) amino acid sequence. Thus, it is possible to study the effect of participating amino acids and to try determining the role of the peptide chain length on the activity of oligopeptides.

There are various methods of formation of a peptide link. We have selected the solid-phase method of synthesis for the oligopeptides presented in this work. As compared to the methods of synthesis in solution, the method applied here shows serious advantages:

- The reaction time for the synthesis of a given peptide is significantly decreased;

- Condensation reactions are carried out quantitatively;

- The resin is washed in order to ease the separation of the excess from the reagents and soluble products;

- Minimum losses of the basic product. 
Carrying out of the peptide synthesis under the Fmocstrategy represents protection of the $\mathrm{N}^{\sigma}$-amino group of the participating amino acid with 9-fluorenylmethoxycarbonyl (Fmoc) group. Its participation does not catalyze side reactions. The applied weakly alkaline processing with piperidine on the synthesized peptide is used to unblock the Fmoc-group of each amino acid. Thus, one of the most important advantages of this strategy is achieved - no continuous unblocking of the protection group is effected and the formed peptide bonds do not break.

Trifluoracetic acid, which is not dangerous when employed, was used for the final separation of the peptide from the resin. Moreover, the laboratory equipment is not expensive and this way the selection of Fmoc-strategy is determined as a highly efficient method of synthesis of compounds.

\section{CONCLUSION:}

1. Modern reagents were used for activation of the carboxylic function of amino acids participating in the solidphase peptide synthesis.

2. An optimal method for preparation of oligopeptides containing basic proteinogenic and non-proteinogenic amino acids was found.

3. It was found that upon application of the Fmocstrategy for synthesis the peptide bond does not destruct (peptide bonds do not break); reagents are safe; the laboratory equipment is not costly.

\section{REFERENCES:}

1. Cammish L. E., Kates S. A., "FmocSPPS: a practial aprproch", W. C. Chan, P.D. White (Eds.), University Press, Oxford; 2000

2. Smith A. J. et al, in: "Techniques in protein chemistry III", R. Angelotti (Ed.), Academic Press; Orlando; 1992; 219

3. Fields G.B. Noble R.L. Solid phase peptide synthesis utilizing 9fluorenylmethoxycarbonyl amino acids. Int.
J. Peptide Protein Res. 1990 Mar;35(3):161-214; doi: 10.1111/j.13993011.1990.tb00939.x [CrossRef] [PubMed] 4. Gordon K., Balasubramancan S.: Solid phase synthesis - Designer Linkers for Combinatorial Chemistry. J. Chem. Tech. Biotech.: 1999 September; 74 (9): 835-851

5. Lloyd-Williams P., Albericio F., Giralt E.: Chemical approaches to the Synthesis of peptides and proteins. University of
Barselona, CRC Pres LLC: 1997

6. Albericio F., Chinchilla R., Dodsworth D. J., Najera C.: New trends in peptide coupling reagents. Org. Prep. Proced. Int.: 2001; 33(3): 202:203-303

7. Kaiser E., Colescott R. L., Bossinger C. D., Cook P. I.: Color test for detection on free terminal amino groups in the solidphase synthesis of peptides. Anal. Biochem. 1970 Apr;34(2):595-598 [PubMed]

\author{
Address for correspondence: \\ Tatyana Hristova, \\ Department of Medical and Biological Sciences, \\ Faculty of Dental Medicine, Medical University - Varna, Bulgaria \\ 76 "Tzar Osvoboditel” Blvd. \\ Tel: $+359898 / 815810$ \\ e-mail: hristova_tatyana@yahoo.com
}

